\title{
The problem of Professional Growth of a Specialist in a Paradigm of Ratio- Humanistic Psychology of George Ball
}

\section{Проблема професійного становлення фахівця в парадигмі раціогуманістичної психології Георгія Балла}

Liudmyla Prymachok

Ph.D. in Pedagogical Sciences, Assistant Professor
Людмила Примачок

кандидат педагогічних наук, доцент

E-mail:primachok73@ukr.net

https://orcid.org/0000-0002-6591-5223

Researcher ID: F-3874-2019

\author{
Scientific Institute \\ of Public Health \\ of National University \\ of Water Management and \\ Nature usage, Rivne, Ukraine \\ 11, Soborna Str., \\ Rivne, 33000
}

Навчально-науковий інститут охорони здоров'я Національного університету водного господарства та природокористування, м. Рівне, Україна вул. Соборна, 11, м. Рівне, Україна, 33000

Original manuscript received April 02, 2019 Revised manuscript accepted April 25, 2019

\section{ABSTRACT}

In this article the features of the research on the process of professional growth of a specialist were specified according to the analysis of contemporary psychological and pedagogical works. The phenomenon of professional development in the paradigm of ratio-humanistic psychology of George Ball 
was revealed. The author's own scientific position (taking into account analyzed ideas of ratio-humanistic psychology) was substantiated, within which it was necessary to study the process of professional development of a specialist in accordance with conditions of obtaining higher professional education and in the process of future professional activity.

It was noted that the relevance of the problem raised in this research was also determined by the fact that if one considered the professional growth of a person in the paradigm of a ratio-humanistic approach, then, in the foreground, there were not only processes of personal development, but also the transformation of the value-semantic foundations of our life, the mechanisms of life self-determination, etc. It was stressed that these problems were also very urgent because the ratio-humanistic paradigm required the search for axiopsychological methods of scientific analysis, which was prerequisite for scientific explanation of the changes that took a main place in the development of the person as a result of the movement of cultural, economic, sociopolitical context of people's existence.

It was determined that ratio-humanistic psychology operated with the concept, which in science was described as "the world of a concrete person». The latter was understood by the author as a "ransitional layer" between objective and subjective realities. Without understanding and recognizing that we permanently are close to having knowledge of the mechanisms of selectivity of mental reflection, the way to understand the mechanisms of the emergence and functioning of human consciousness, which are the basis for professional growth of the person.

It was noted that the process of professional growth of a future specialist was considered as the development of personal potential and resources of the subject that would promote self-development and self-realization in the paradigm of universal culture, taking into account the specific conditions of the professional activity in the process of mastering and reproduction by a specialist professionally meaningful norms and values.

Key words: professional growth, ratio-humanistic psychology, ratio-humanistic paradigm, self-development, self-realization, meaningful norms and values, axiopsychological methods of the analysis.

\section{Вступ}

Проблема професійного становлення особистості не є зовсім новою в психологічній царині, проте існують різноманітні, нерідко - протилежні точки зору на цю проблему, тому нею слід займатися спеціально. Наприклад, у психо- 
лого-педагогічний тезаурус I. М. Семенов (Селёнов, 1995) увів поняття «мотиваційне поле професійної взаємодії», яке характеризується наявністю мотивів учасників взаємодії, що спонукає їх брати участь у спільній діяльності та спілкуванні. За аналогією з теорію поля К. Левіна (Левин, 2000) взаємодія суб'єктів освітньої діяльності розглядається автором як функція мотиваційного поля, утвореного досить взаємозалежними чинниками, які значною мірою впливають на цей процес. Отже, мотиваційне поле виникає тоді, коли є чітко окреслена сфера загальних професійних інтересів. Якщо міжособистісна взаємодія має місце тільки у процесі спілкування, то цикл комунікації великою мірою обмежений визначенням загальних соціальних інтересів, формуванням мотиваційного поля соціальної взаємодії та розширенням сфери соціальних інтересів. Якщо взаємодія - досить предметна, професійно зорієнтована, то за умов наявності загального соціального інтересу і мотиваційного поля професійної взаємодії, яке виникає на цій основі, виокремлюється предмет спільної професійної діяльності, визначаються їі цілі, проектується комплекс спільних професійних дій, відбувається реалізація цілей професійної діяльності, здійснюється поетапний аналіз професійно значущих дій, має місце корекція соціальної поведінки і діяльності тощо. Унаслідок цього відбувається значне розширення сфери професійних інтересів фахівців.

Характеристиками мотиваційного поля є динамічність і стабільність (остання забезпечує збереження системи взаємодії, її стійкість, а динамічність, у свою чергу, забезпечує постійний розвиток системи), спрямованість (виявляється у зміні спрямованості спільної професійної діяльності - на себе, предмет діяльності, один на одного), адекватність цілям професійної взаємодії тощо.

Досліджуючи особливості процесу професіоналізації, а саме наголошуючи на тому, що поведінка одного суб'єкта завжди пов'язана з поведінкою інших і взаємодія в професійній організації визначається мотивами учасників ді- 
яльності, Д. Б. Ельконін (Эльконин, 1989; Кnарp, 1975) обгрунтовує поняття «поле професійної самореалізації» . Учений розглядає процес професійної самореалізації як функцію поля, що утворюється взаємозалежними чинниками, які впливають на цей процес. 3 одного боку, зміна умов професійної самореалізації суб'єктів змінює їхні мотиви діяльності та їх самих; з іншого боку, вплив на учасників процесу професійної самореалізації впливає на поле професійної самореалізації та всю досліджувану систему загалом.

Під полем професійної самореалізації автор розуміє наявність різних можливостей для майбутніх фахівців реалізовувати свої особисті соціально-значущі інтереси та потреби, котрі надає їм професійній простір у процесі організації спільної діяльності, розширення сфери спілкування, формування рефлексивної позиції тощо (Эльконин, 1989).

Створення поля професійної самореалізації припускає таку організацію педагогічно регульованої діяльності (Михальчук, 2012), що сприятиме максимальному прояву індивідуального (особистісного) потенціалу у великої кількості членів організації, оптимізацію стилю взаємостосунків між членами певного професійного колективу, між професійними установами, їхніми лідерами і представниками, створення у професійному просторі передумов для співробітництва, взаєморозуміння, взаємодії, використання методик варіативно-програмного підходу й особистісно зорієнтованого навчання.

Спираючись на аналіз теоретичної літератури, ми розглядаємо поле професійного становлення як сферу професійної діяльності фахівців, педагогів освітніх навчальних закладів, професійних об’єднань і громадських організацій, професійних клубів тощо, у яких реалізуються різні за вектором виховні системи, що визначатимуть унікальну за змістом персональну траєкторію соціального становлення кожного спеціаліста.

Слід наголосити, що різні поля професійного станов- 
лення сприйматимуться нами як сукупність передумов, у яких це становлення відбувається, що визначатиметься змістом педагогічно регульованої діяльності, організованої викладачами для майбутніх фахівців (ідеться про викладачів, які опинилися у певний момент життя в тому чи іншому професійному полі).

Розглядаючи процес професійного становлення молоді, Л. М. Собчик (Собчик, 1998) і Л. Корпорович (Korporowicz, 1993) зазначають, що це - становлення, передусім, сутності індивіда, основною характеристикою якої є відповідальність перед самим собою й оточуючими, сформована в умовах постійного морального, соціального, економічного вибору. Професійне становлення - це процес становлення індивідуальності, результатом якого є сформовані особистісні характеристики індивіда, що зазнають «добудову» $\mathrm{i}$ розвиток упродовж усього життя фахівця.

Отже, можна констатувати, що, як правило, термін «професійне становлення» використовується в трьох значеннях: як синонім категорії «розвиток»; як експлікація процесу створення передумов, детермінантів, що виникають на основі розвитку; як характеристика початкового етапу набуття професіоналізму, коли відбувається перехід від старого до нового, зростання цього нового, його зміцнення і перетворення в цілісну гармонійну систему.

Отже, проблема професійного становлення - одна 3 найдавніших філософських проблем. У загальноприйнятому науковому розумінні ця категорія експлікує значення спонтанності, мінливості речей і явищ, їх безперервний перехід, перетворення в інший стан тощо.

У соціологічних теоріях існує відмінність між розумінням процесів професійного становлення та розвитку. Передусім, наголошується, що професійне становлення у своїй основі орієнтується на випадкове набагато більшою мірою, ніж розвиток, зумовлений сприятливим збігом чинників та умов, які є цілковито випадковими за своєю природою. Процес професійного становлення можна адекватно оціни- 
ти лише постфактум, відстежуючи за причинно-наслідковим зв'язком тих етапів, що вже мали місце.

Деякі сучасні автори (Онуфрієва, 2013; Lakin, 1972) визначають професійне становлення як процес розвитку, в якому індивід бере на себе відповідальність за максимально повну реалізацію свого особистісного потенціалу, як набуття нових ознак й оволодіння новими формами виконання діяльності у процесі розвитку, наближення до певного стану тощо. У цьому контексті прийнято говорити про оновлення людини, збагачення її особистості, характеру, мислення або про духовно-моральне, інтелектуальне, соціальне становлення тощо.

Зважаючи на проаналізовані праці з окресленої проблеми, мета статті - розглянути феномен професійного становлення особистості в парадигмі раціогуманістичної психології Георгія Балла та зробити власні висновки щодо продуктивності такого становлення майбутнього фахівця.

\section{Завдання статті}

1. Уточнити особливості дослідження професійного становлення фахівця з огляду на аналіз сучасних психолого-педагогічних праць.

2. Розкрити феномен професійного становлення в парадигмі раціогуманістичної психології Георгія Балла.

3. Обгрунтувати власне авторську дослідницьку позицію (з урахуванням проаналізованих ідей раціогуманістичної психології), в межах якої вивчатимемо процес професійного становлення фахівця в умовах здобуття ним вищої професійної освіти та в майбутній фаховій діяльності.

\section{Методи дослідження}

Для розв'язання поставлених у роботі завдань використовувалися такі теоретичні методи дослідження: категоріальний, структурно-функціональний, аналіз, систематизація, моделювання, узагальнення.

\section{Результати та дискусії}


Уточнення особливостей дослідження професійного становлення фахівця з усією однозначністю визначає необхідність пошуку і визначення нових методологічних підходів аналізу вищої професійної освіти як психологоакмеологічного процесу, що дозволяє визначити базові та додаткові характеристики, які фасилітують професійне становлення фахівця. Так, професійне становлення людини набуває поступального характеру, не зважаючи на те, що різні наукові школи підходять до розв'язання одного і того ж предмета дослідження з різних (іноді - несумісних) точок зору. Ми приймаємо поліпарадигмальний характер психології, в тому числі - до предмета професійного становлення особистості, що значно розширює можливості розв'язання дослідницьких завдань із використанням різних засобів і організаційних форм емпіричної діяльності, з урахуванням позицій різних психологічних шкіл і підходів.

Отже, обгрунтуємо власне авторську дослідницьку позицію, в межах якої вивчатимемо процес професійного становлення фахівця в умовах здобуття ним вищої професійної освіти та в майбутній фаховій діяльності. Останнє дає змогу розкрити, в нашому розумінні, зовсім новий підхід щодо досліджуваного феномену в співвідношенні предмета дослідження до об’єкта, методу, дослідницького завдання тощо; теоретично обгрунтувати дефініцію професійного становлення, розкрити її методологічний базис і виокремити структуру цього феномену; здійснити побудову диспозитивних схем (конфігураторів), які об’єктивують і тлумачать зазначену дефініцію (що дозволятиме визначити психологічні умови, чинники й особливості професійного становлення фахівця); формулювання нового підходу щодо методології вивчення цього феномену; оптимізація (удосконалення) існуючих практик вищої професійної освіти і конституювання нової практики (психолого-раціогуманістичної) в контексті необхідних методологічних і те- 
оретичних міркувань та уявлень автора.

Із метою вивчення професійного становлення фахівця ми звертаємось до уявлення про науку як відкриту самоорганізовану систему, що дає змогу розглядати досліджувані явища в динаміці (Ломов, 1975). Із точки зору теорії психологічних систем, будь-яка наука починається зі статики, з вивчення того, що вже сталося, відбулося, але згодом переходить до вивчення динаміки процесу становлення, виокремлюючи особливості й тенденції розвитку, тому трансспективний аналіз можна застосувати, в тому числі, до онтогенезу як детермінанти становлення людини як самоорганізованої психологічної системи.

Для нашого дослідження актуальною є проблема місця і ролі психічного у взаємовідносинах людини з усім простором, який знаходиться за межами її особистості. Ми дотримуємося поглядів Г. С. Костюка (Костюк, 1994), який вважає, що і психіка, і свідомість особистості є не що інше, як найбільш потужний, витончений, найбільш складний із відомих психічних механізмів, який перетворює «світ для себе» у «світ для нас» (ідеться про багатовимірний світ людини), який дозволяє діяти, розуміючи сенс і цінність своїх дій, їх наслідки тощо.

Для нашої статті є важливим розуміння того, що повнота дослідження феномену професійного становлення має розглядатися в парадигмі раціогуманістичної психології Г. О. Балла (Балл, 2014), адже саме ця теоретико-методологічна парадигма дає змогу аналізувати феномен професійного становлення як форму самоорганізації людини як цілісної психологічної системи. Проте самоорганізація постає гармонійним процесом тільки з точки зору системного бачення людини, оскільки поза таким підходом саме поняття самоорганізації втрачає будь-який сенс - вона є, передусім, властивістю й ознакою самоорганізованих систем, саме тому можна вважати актуальним завдання вивчення професійного становлення в контексті теорії психо- 
логічних систем.

Можливості теорії психологічних систем у парадигмі раціогуманістичної психології щодо проблеми, яка вивчається, дають змогу вирішити методологічні труднощі професійного становлення, пов'язані зі зверненням до цього процесу як до системи, яка припускає досягнення більш оптимального способу організації психіки особистості, що дозволяе визначати людину як предмет психологічного пізнання у процесі гармонійного розвитку. Саме раціогуманістична психологія дає змогу визначати процес професійного становлення людини як ціннісно-смисловий, аксіологічний тощо. Останнє створюе неабиякі можливості для розгляду соціальної взаємодії як детермінанти самоорганізації людини як психологічної системи, що загалом фасилітує професійне зростання фахівця.

У контексті теорії психологічних систем також постає можливим розгляд процесу професійного становлення як виникнення особистісних новоутворень, що включаються у функціонування психічної системи людини, у якій самоорганізація постає як базова передумова організації особистісного розвитку. Останне дає підстави вважати, що в цьому процесі змінюється вміст власне особистісного в людині, яке і породжується, виробляється кожним актом соціальної взаємодії, включеним у діяльність, спрямовану на світ, на іншого, на себе, що постає унікальним засобом самоздійснення, самореалізації, саморозвитку (Балл \& Папуча, 2007). Отже, професійне становлення особистості вимагає, передусім, актуалізацію активності, що визначатиме також і зміст діяльності, спрямованої на творення людиною самої себе, формування власної особистості як гармонійної цілісності тощо.

Отже, саморух, саморозвиток властиві будь-яким відкритим самоорганізованим системам. Тому, розуміючи професійне становлення в самому загальному вигляді як адекватний для свідомої людини процес саморозвитку, ми розумітимемо цей процес як такий, що характеризується 
прогресивною спрямованістю (конструктивна інтенція), інтенсивністю (лавиноподібний динамізм), принциповою незавершеністю (відкритість до наступного етапу розвитку). Отже, професійне становлення ми вважатимемо іманентною, інваріантною ознакою, що загалом відповідає природі людини.

Актуальність проблематики, яка порушується в нашому дослідженні, зумовлюється також і тим, що якщо розглядати професійне становлення людини в парадигмі раціогуманістичного підходу, то на першому плані постають не лише процеси особистісного розвитку, а й трансформації ціннісно-смислових основ буття, механізмів життєвого самовизначення тощо. Актуальними ці проблеми є ще й тому, що раціогуманістична парадигма потребує пошуку аксіопсихологічних методів аналізу, що є необхідною умовою для наукового пояснення змін, які відбуваються в розвитку особистості як результат руху культурного, економічного, соціально-політичного контексту їхнього буття.

Отже, професійна діяльність - це система, що має свою власну будову, свої внутрішні механізми, свій розвиток. Особистість - це система, що розвивається, а процес професійного становлення особистості можна уявити собі як розгортання цілісної органічної системи, у якій кожна частина припускає іншу і загалом породжується цією цілісною системою (Карпенко, 1998). Кожна система, у свою чергу, забезпечує здатність особистості до саморуху, саморозвитку, виходу за межі самого себе. Ці здатності й зумовлюють процес професійного становлення, але розв'язання цієї проблеми потребує виходу на вищий рівень системності, що й фасилітує формування особистісних новоутворень індивіда (Калмыкова \& Калмыков, 2015).

Саме внаслідок цього професійне становлення пов' язане з відкриттям метасистеми, відносно якої ізольовані досі моносистеми не можуть бути визначені як підсистеми, тобто елементи моносистеми. Останнє дозволить здійснити інтеграцію всіх ізольованих моносистем (особистість, психі- 
ка, діяльність, природна і соціальна системи), дасть змогу уявити їх взаємодію і виокремити (актуалізувати тощо) ті продукти взаємодії, що визначатимуть подальший розвиток тієї інтегративної цілісної системи, у якій поєднані всі моносистеми, і в межах якої вони постають як взаємодіючі підсистеми. Таку інтегративну цілісність ми визначаємо як психологічну систему, яка й забезпечує професійне становлення фахівця. У свою чергу, ця психологічна система сприяє так званому вільному ініціюванню мислення як пізнавальної діяльності (Михальчук \& Івашкевич, 2018; Онуфрієва, 2013), яка виявилась дуже вдалою моделлю для вивчення професійно спрямованої поведінки людини надситуативної, практичної або непрактичної, адаптивної або неадаптивної чи то дезадаптивної, нормативної або ненормативної чи то наднормативної тощо.

3 урахуванням позицій раціогуманістичної психології людина розуміється як самоорганізована система, тобто система, що породжує виникнення психологічних новоутворень і орієнтується саме на них у своєму саморусі (Балл, 2014). В основу цієї теорії покладено уявлення щодо «породжувального ефекту міжособистісної взаємодії» (Балл \& Папуча, 2007). Іншими слова, існують такі характеристики явищ, що виникають у системі, породжуються системою і забезпечують особистості можливість самоорганізації. Отже, система розширюється за рахунок взаємодії із зовнішнім, яке, у свою чергу, переходить у внутрішній зміст. Тільки стаючи внутрішнім змістом людини як психологічної системи, зовнішне виявляється дійсно «внутрішнім» (не-Я) для сприймання самою людиною, її свідомістю, ïi «Я» тощо.

Тому раціогуманістична психологія оперує поняттям, яке в науці описується як «світ конкретної людини». Останній розуміється як «перехідний шар» між об'єктивною й суб'єктивною реальностями, не зрозумівши і не визнавши який, ми назавжди закриваємо шлях до пізнання механізму вибірковості психічного відображення, шлях до розу- 
міння механізмів виникнення і роботи людської свідомості, що є основою для професійного становлення особистості.

Раціогуманістична психологія наголошує, що «світ людини» виявляється частиною самої людини, є ніби її продовженням, її істинною характеристикою. Характерною особливістю цього ніби «олюдненого» простору є його багатовимірність, що виникає внаслідок інтеграції в його структурі об'єктивних і суб'єктивних вимірів (Брутян, 1973).

Коли йдеться про становлення «людського в людині», то за логікою раціогуманістичної психології багатовимірний світ людини визначає становлення певного способу життя. Стаючи суверенною особистістю, тобто особистістю, яка усвідомлює всю повноту багатовимірного світу, людина отримує можливість змінювати спосіб життя, стимулюючи тим самим подальший розвиток власного світу. В розв'язанні протиріч між способом світу і способом життя фахівця проходить і саме життя людини. Основною функцією мислення в реальній професійній діяльності, зазначають О. Ф. Волобуєва (Волобуєва, 2014), Р. Лазарус і В. Арнольд (Lazarus \& Arnold, 1968), є постійне виявлення зазначеного протиріччя, що й визначає способи професійного становлення фахівця певної галузі.

У парадигмі раціогуманістичної психології саморозвиток і самодетермінація також постають необхідною умовою професіоналізації. Ідеться не про саморозвиток заради самого розвитку, не саморозвиток як певний найвищий i неусвідомлюваний нами сенс життя, а розвиток заради життя, розвиток як спосіб життя, гетеростаз - як різнорідний, без кордонів нормотворний рух, спосіб буття людини в якості самоорганізованої психологічної системи.

Психологічна система, яка фасилітує професійне становлення особистості, власне і постає предметом нашого психологічного дослідження. Багатовимірний світ людини розуміється нами як особливий простір, який формується у процесі життєдіяльності, ускладнюється з огляду на на- 
буття нею нових якостей, властивостей, характеристик. При цьому професійне становлення поступово починає розглядатися поєднано із суб'єктивним часом, пов'язаним із параметрами простору. Час у психологічних системах змінюється з огляду на становлення нових координат світу людини.

Отже, раціогуманістична психологія розуміє людину як складну систему, центром якої є людина як біосоціальна істота, а психіка розглядається як те, за допомогою чого забезпечується професійна діяльність людини в ï предметних ціннісно-смислових полях, здійснюється й утримується перехід суб’єктивного (поточні стани людини) в предметний світ і реалізується колоподібний рух світу в свідомості людини. При цьому ціннісні координати світу людини роблять їі співвимірними з іншими людьми, із самою собою - завтрашньою, якою ще особистість не стала, ще тільки можливою, що дає змогу розуміти професійну дійсність, яка відкривається для фахівця, простором для розвитку, самовдосконалення та професійного зростання.

Раціогуманістична психологія робить своїм предметом дослідження процес породження і становлення цієї психологічної онтології, переносячи центр тяжіння в емпіричних дослідженнях у простір реальної життєдіяльності туди, де й відбувається справжній процес становлення особистості, здійснюється реальний цикл життєздійснення.

Розуміння людини як самоорганізованої системи викладено у раціогуманістичних наукових теоріях: упошуках «перехідних форм» між духом і матерією Л. С. Виготського (Выготский, 1982), у «життєвих» i «транссуб'єктних» просторах Г. Гріандіса (Гріандіс, 2019), у «багатовимірному образі світу» О. М. Леонтьєва (Леонтьев, 1977). Так, стає зрозумілим, що з переходом до парадигми системного методологічного контексту можна зрозуміти, яким чином людині вдається не бути рабом «об'єктивних ситуацій», соціальних доменів, і звідки виникає у неї унікальна здатність до самодетермінації, що забезпечує їй можливість са- 
морозвитку і впливу на себе.

Сутність раціогуманістичної психології полягає в переході від дотримання принципу відображення до принципу породження особливої психологічної (непсихічної) онтології, яка являє собою системний конструкт, що значною мірою опосередковує взаємовідносини між людиною та світом «чистої» об’єктивності. О. М. Леонтьєв (Леонтьев, 1977) називав світ «чистої» об’єктивності «амодальним світом»), що забезпечує перетворення амодального світу в опанований людиною простір, що постає його індивідуальною характеристикою професійної діяльності. У парадигмі раціогуманістичної психології розглядається процес породження таких системних новоутворень, які включаються в подальшу регуляцію системи, що і перетворює саморегулюючу систему в самоорганізований професійний простір.

\section{Висновки}

Отже, власне психологічна онтологія породжується не людиною, не її свідомістю, а цілісністю психологічної системи, центром якої є людина, її особистісний і професійний розвиток. Але саме вона забезпечує можливість виникнення і функціонування свідомості, яка є первинною відносно першої, але вторинною по відношенню до амодального світу.

Можна констатувати, що, як правило, термін професійного становлення використовується в трьох значеннях: як синонім категорії «розвиток»; як експлікація процесу створення передумов, чинників, які зумовлюють цей процес; як характеристику певного стану, коли відбувається перехід від старого до нового, зростання цього нового, його зміцнення і перетворення в цілісну гармонійну систему.

Отже, проаналізувавши різні наукові підходи до розуміння професійного становлення, ми розуміємо під цим процесом розвиток особистісних потенціалів і ресурсів суб’єкта, які сприятимуть саморозвитку та самореалізації в парадигмі загальнолюдської культури, з урахуванням 
конкретних умов професійної діяльності у процесі опанування та відтворення фахівцем професійно значущих норм і цінностей.

\section{Література}

Балл Г. О., Папуча М. В. Діалогічність як форма існування і розвитку особистості. Ніжин : Міланик, 2007. 343 с.

Балл Г. А. Системная трактовка культуры и личности в контексте концепции рациогуманизма. Наука і освіта. 2014. № 9/CXXVI. С. 26-31.

Брутян Г. А. Язык и картина мира. Науч. доклады высш. шк. философ. науки. 1973. № 1. С. 84-112.

Волобуєва О. Ф. Професійна діяльність сучасного викладача вищої школи: виклики та пріоритети. Збірник наукових праць Національної академії Державної прикордонної служби Украӥни. Сер.: Педагогічні та психологічні науки. 2014. № 4. С. 392-406. Режим доступу : http://nbuv.gov.ua/UJRN/znpnapv_ppn_2014_4_36.

Выготский Л. С. Проблема сознания (запись основных положений доклада Л. С. Выготского). Т. 1. Москва : Педагогика, 1982. С. 156167.

Гріандіс Г. Культуро-специфічний тренінг. 2019. Режим доступу : https://www.sspu.sumy.ua/index.php?option=com_content\&.

Калмыкова Л. А., Калмыков Г. В. Концептуальные подходы к совершенствованию психологической подготовки будущих педагогов. Материаль конф. "Педагогика и психология как ресурс развития совреленного общества: проблель сетевого взаилодействия в инклюзивнол образовании». 2015. С. 238-243.

Карпенко 3. С. Аксіопсихологія особистості. Київ : ТОВ «Міжнародна фінансова агенція», 1998. 216 с.

Костюк Г. С. Принцип развития в психологии. Москва : МГУ, 1994. С. 19-22.

Левин К. Теория поля в социальных науках. Санкт-Петербург : Язык, 2000. $126 \mathrm{c.}$

Леонтьев А. Н. Деятельность. Сознание. Личность. Москва : Политиздат, 1977.304 с.

Ломов Б. Ф. О системном подходе в психологии. Вопросы психологии. 1975. № 2. С. 94.

Михальчук Н. О. Психологія читання та розуміння літературних творів старшокласниками. Київ : ТОВ «Принт Хауз», 2012. 368 с.

Михальчук Н. О., Івашкевич Е. 3. Психолінгвістичне опанування читацької діяльності як аксіологічного процесу. Матеріали Все української (з міжнародною участю) наук.-пр. конф. «Сучасні 
соціокультурні та психолого-педагогічні координати розвитку дитини». Тернопіль, 19.04-20.04.2018 р. С.104-107.

Онуфрієва Л. А. Дослідження психологічних детермінант розвитку професійної самосвідомості та особистісної зрілості майбутніх фахівців соціономічних професій. Науковий вісник Миколаївського державного університету ілені В.О. Сухоллинського. Серія «Психологічні науки» / За ред. С. Д. Максименка, Н. О. Свдокимової. Миколаїв : МНУ імені В.О.Сухомлинського, 2013. Т. 2. Вип. 10 (91). С. 227-233.

Селёнов И. Н. Рефлексивно-творческий подход в непрерывном профессиональном образовании. Бийск : БГПИ, 1995. 113 с.

Собчик Л. Н. Введение в психологию индивидуальности. Москва : Институт прикладной психологии, 1998. 120 с.

Эльконин Д. Б. Избранные психологические труды / Под ред. В. В. Давыдова, В. П. Зинченко; авт. вступ. ст. и коммент. В. В. Давыдова. Москва : Педагогика, 1989. 554 с.

Knapp, A. (1975). Über den Lernerforlg im Kleingruppen Unterricht und seine bedingten Faktoren. Frankfurt : Frankfurt am Main. 101 s.

Korporowicz, L. (1993). Tworzenie sensu: jezyk - kultura - komunikacja. Warszawa : W-two «Oficyna naukowa Warszawa». $188 \mathrm{~s}$.

Lakin, M. (1972). Interpersonal encounter. Theory and practice in sencitizity training. New York : Penguin Books. $302 \mathrm{p}$.

Lazarus, R. S., \& Arnold, W. J. (1968). Emotion and adaptation: Conceptual and empirical relations. Nebraska Symposium on Novigation. New York : Penguin Books. 113 p.

\section{References}

Ball, G. O., \& Papucha, M. V. (2007). Dialohichnist yak forma isnuvannia $i$ rozvytku osobystosti [Dialogism as a form of the existence and the development of the personality]. Nizhyn : Milanik [in Ukrainian].

Ball, G. A. (2014). Sistemnaja traktovka kul'tury i lichnosti v kontekste kontseptsii ratsiogumanizma [Systematic interpretation of culture and personality in the context of the concept of racio-humanism]. Nauka i osvita - Science and education, 9/CXXVI, 26-31 [in Russian].

Brutjan, G. A. (1973). Jazyk i kartina mira [Language and the image of world]. Nauch. doklady vyssh. shk. filosof. nauki-Scientific reports of higher school of philosophical science, 1, 84-112 [in Russian].

Volobuieva, O. F. (2014). Profesiina diialnist suchasnoho vykladacha vyshchoi shkoly: vyklyky ta priorytety [Professional activity of a teacher of a contemporary high school: challenges and priorities]. Zbirnyk naukovykh prats Natsionalnoi akademii Derzhavnoi prykordonnoi sluzhby Ukrainy - Collection of research works of the $\mathrm{Na}$ - 
tional Academy of the State Border Guard Service of Ukraine. Series: Pedagogical and psychological sciences, 4, 392-406. Retrieved from http://nbuv.gov.ua/UJRN/znpnapv_ppn_2014_4_36[in Ukrainian].

Vygotskij, L. S. (1982). Problema soznanija (zapis' osnounyh polozhenij doklada L. S. Vygotskogo) [The problem of consciousness (recording of the main points of the report done by L. S. Vygotskyi)], 1, 156-167. Moskva : Pedagogika [in Russian].

Hriandis, H. (2019). Kulturo-spetsyfichnyi treninh [Cultural specific training]. Retrieved from https://www.sspu.sumy.ua/index. php?option=com_content\& [in Ukrainian].

Kalmykova, L. A., \& Kalmykov, G. V. (2015). Kontseptual'nye podhody k sovershenstvovaniju psihologicheskoj podgotovki budushchih pedagogov [Conceptual approaches to improving the psychological training of future teachers]. Materialy konf. "Pedagogika i psihologija kak resurs razvitija sovremennogo obshchestva: problemy setevogo vzaimodejstvija $v$ inkljuzivnom obrazovanii» - Proceedings of the conference "Pedagogy and psychology as a resource for the development of modern society: problems of network interaction in inclusive education»]. (pp. 238-243) [in Russian].

Karpenko, Z. S. (1998). Aksiopsykholohiia osobystosti [Axiopsychology of the personality]. Kyiv : TOV «Mizhnarodna finansova ahentsiia» [in Ukrainian].

Kostjuk, G. S. (1994). Printsip razvitija $v$ psihologii [The principle of the development in psychology]. Moskva : MGU [in Russian].

Levin, K. (2000). Teorija polja v sotsial'nyh naukah [Field Theory in Social Sciences]. Sankt-Peterburg : Rech' [in Russian].

Leont'ev, A. N. (1977). Dejatel'nost'. Soznanie. Lichnost' [Activity. Consciousness. Personality]. Moskva : Politizdat [in Russian].

Lomov, B. F. (1975). O sistemnom podhode v psihologii [About the system approach in 3sychology]. Voprosy psihologii-Issues on Psychology, 2, 94 [in Russian].

Mykhalchuk, N. O. (2012). Psykholohiia chytannia ta rozuminnia literaturnykh tvoriv starshoklasnykamy [Psychology of reading and understanding of novels by senior pupils]. Kyiv : TOV «Priynt Khauz» [in Ukrainian].

Mykhalchuk, N. O., \& Ivashkevych, E. Z. (2018). Psykholinhvistychne opanuvannia chytatskoi diialnosti yak aksiolohichnoho protsesu [Psycholinguistic mastering of readership as an axiological process]. Materialy Vseukrainskoi ( $z$ mizhnarodnoiu uchastiu) nauk.-pr. konferentsii "Suchasni sotsiokulturni ta psykholoho-pedahohichni koordynaty rozvytku dytyny" - Proceedings of all-Ukrainian (with international participation) scientific conference "Modern socio-cultural and psychological and pedagogical coordinates of child's develop- 
ment». (pp. 104-107). Ternopil [in Ukrainian].

Onufriieva, L. A. (2013). Doslidzhennia psykholohichnykh determinant rozvytku profesiinoi samosvidomosti ta osobystisnoi zrilosti maibutnikh fakhivtsiv sotsionomichnykh profesii [Research on psychological determinants of the development of professional self-consciousness and personal maturity of future specialists of sociological professions]. S. D. Maksymenko, N. O. Evdokimova (Eds.). Naukovyi visnyk Mykolaivskoho derzhavnoho universytetu imeni V. O. Sukhomlynskoho - Scientific Newsletter of Mykolaiv V.O. Sukhomlynskyi State University. Series "Psychological Sciences», 2, Vol. 10 (91), 227-233. Mykolaiv [in Ukrainian].

Semenov, I. N. (1995). Refleksivno-tvorcheskij podhod v nepreryvnom professional'nom obrazovanii [Reflexive-creative approach in continuous professional education ]. Bijsk : BGPI [in Russian].

Sobchik, L. N. (1998). Vvedenie $v$ psihologiju individual'nosti [Introduction into the psychology of individuality]. Moskva : Institut prikladnoj psihologii [in Russian]

Jel'konin, D. B. (1989). Izbrannye psihologicheskie trudy [Selected psychological researches ]. V. V. Davydova, V. P. Zinchenko (Eds.). Moskva : Pedagogika [in Russian].

Knapp, A. (1975). Über den Lernerforlg im Kleingruppen Unterricht und seine bedingten Faktoren. Frankfurt : Frankfurt am Main [in Ger$\operatorname{man}]$.

Korporowicz, L. (1993). Tworzenie sensu: jezyk - kultura - komunikacja. Warszawa : W-two «Oficyna naukowa Warszawa» [in Polish].

Lakin, M. (1972). Interpersonal encounter. Theory and practice in sencitizity training. New York : Penguin Books.

Lazarus, R. S., \& Arnold, W. J. (1968). Emotion and adaptation: Conceptual and empirical relations. Nebraska Symposium on Novigation. New York : Penguin Books.

Примачок Людмила. Проблема професійного становлення фахівця в парадигмі раціогуманістичної психології Георгія Балла

\section{АНОТАЦІЯ}

у статті уточнено особливості дослідження професійного становлення фахівця з огляду на аналіз сучасних психолого-педагогічних праць. Розкрито феномен професійного становлення в парадигмі раціогуманістичної психології Георгія Балла. Обгрунтовано власне авторську дослідницьку позицію (з урахуванням проаналізованих ідей раціогуманістичної психології), у межах якої слід вивчати процес профресійного становлення фахівця в умовах здобуття ним вищої професійної освіти 
та в майбутній фаховій діяльності.

Зазначено, що актуальність проблематики, яка порушується в цьому дослідженні, зумовлюється також і тим, що якщо розглядати профресійне становлення людини в парадигмі раціогуманістичного підходу, то на першому плані постають не лише процеси особистісного розвитку, а й трансформації ціннісно-смислових основ буття, механізмів життєвого самовизначення тощо. Наголошено, шо актуальними ці проблеми є ще й тому, що раціогуманістична парадигма потребує пошуку аксіопсихологічних методів аналізу, що є необхідною умовою для наукового пояснення змін, які відбуваються в розвитку особистості як результат руху культурного, економічного, соціально-політичного контексту їхнього буття.

Визначено, що раціогуманістична психологія оперує поняттям, яке в науці описується як «світ конкретної людини». Останній розуміється автором статті як "перехідний шар» між об'єктивною та суб'єктивною реальностями, не зрозумівши і не визнавши який, ми назавжди закриваємо шлях до пізнання механізму вибірковості психічного відображення, шлях до розуміння механізмів виникнення і роботи людської свідомості, що є основою для професійного становлення особисmocmi.

Зазначено, що під процесом профресійного становлення майбутнього фрахівия розуміється розвиток особистісних потенціалів $і$ ресурсів суб'єкта, які сприятимуть саморозвитку та самореалізації в парадигмі загальнолюдської культури, з урахуванням конкретних умов профресійної діяльності у процесі опанування та відтворення фахівцем профресійно значущих норм і иінностей.

Ключові слова: професійне становлення, раціогуманістична психологія, раціогуманістична парадигма, саморозвиток, самореалізація, значущі норми і цінності, аксіопсихологічні методи аналізу.

\section{Примачок Людмила. Проблема профессионального становления специалиста в парадигме рациогуманистической психологии Георгия Балла}

\section{АННОТАЦИЯ}

В статье уточнены особенности исследования профессионального становления специалиста исходя из анализа современных психологопедагогических трудов. Раскрыт феномен профессионального становления в парадигме рациогуманистической психологии Георгия Балла. 
Обоснована собственно авторская исследовательская позиция (с учетом проанализированных идей рациогуманистической психологии), в рамках которой следует изучать процесс профессионального становления специалиста в условиях получения им высшего профессионального образования и в будущей профессиональной деятельности.

Отмечено, что актуальность проблематики, которая поднимается в данном исследовании, обусловлена также и тем, что если рассматривать профессиональное становление человека в парадигме рациогуманистического подхода, то на первом плане фиксируются не только процессы личностного развития, но и трансформации иенностно-смысловых основ бытия, механизмов жизненного самоопределения и др. Отмечено, что актуальными эти проблемы являются еще и потому, что рациогуманистическая парадигма требует поиска аксиопсихологического метода анализа, и этот метод является необходимым условием для научного объяснения изменений, которые происходят в развитии личности как результат движения культурного, экономического, социально-политического контекста бытия.

Определено, что рациогуманистическая психология оперирует понятием, которое в науке описывается как «мир конкретного человека». Последний понимается автором статьи как "переходный скрипт» между объективной и субъективной реальностями, не поняв и не признав который мы навсегда закрываем путь к познанию механизма избирательности психического отражения, путь к пониманию механизмов возникновения и работы человеческого сознания, что, безусловно, является основой для профессионального становления личности.

Отмечено, что под процессом профессионального становления будущего специалиста понимается развитие личностных потенциалов и ресурсов субъекта, способствующих саморазвитию и самореализации в парадигме общечеловеческой культуры, с учетом конкретных условий профессиональной деятельности в процессе освоения и воспроизведения специалистом профессионально значимых норм и ченностей.

Ключевые слова: профессиональное становление, рациогуманистическая психология, рациогуманистическая парадигма, саморазвитие, самореализация, значимые нормы и ценности, аксиопсихологические методы анализа. 